УДК 697.98;69:504

О.В. Мурасьова, заступник завідувача відділу

ДП “Науково-дослідний інститут будівельного виробництва”, м. Київ

І.М. Уманець, к.т.н., доц. каф. ТБВ

Київський національний університет будівництва і архітектури, м. Київ

\title{
ЗАСОБИ ІНЖЕНЕРНОГО ЗАХИСТУ ТЕРИТОРІЙ ПОЛІГОНІВ ТВЕРДИХ ПОБУТОВИХ ВІДХОДІВ
}

\begin{abstract}
Анотація. У статті проаналізовано заходи інженерного захисту територій, які можуть бути впроваджені при рекультивації полігонів твердих побутових відходів. Це - зміна рельєфів схилів до нормативних ухилів 1:3,2, регулювання стоку поверхневих вод; захист поверхонь схилів від інфільтрації зливових і талих вод у грунт та ерозійних процесів, тобто влаштування багатофункціоналвного захисного шару (суглинок 25 см; газовий дренаж 30 см; геотекстиль 3,5 мм; геомембрани НDPE 1,5 мм; пісок 20 см; суглинок 20 см; родючий грунт 30 см; георешітка на укосах), дренажі для відводу фільтрату, підпірна стінка, стримувальні протизсувні споруди, агролісомеліораціл. Запропоновано конструктивні рішення заходів інженерного захисту територій полігонів твердих побутових відходів в декількох варіантах та технологї їх влаштування.
\end{abstract}

Ключові слова:. зміна рельєфів схилів; захисний екран; дренаж; підпірна стінка; стримувальні протизсувні споруди; агролісомеліорація.

\section{Постановка проблеми}

Полігони твердих побутових відходів формуються 3 відходів від житлових будинків, громадських підприємств, підприємств торгівлі, громадського харчування та інших галузей господарської діяльності людини. Існуюча в Україні система об'єднаного збору ТПВ без розділення на органічні і неорганічні компоненти посилює недоліки технології зберігання відходів на полігоні [6].

Орієнтовний склад фракцій ТПВ від житлового сектору за даними Академії комунального господарства наведено в таблиці 1 [7].

Технологія складування ТПВ на полігоні поярусна з поділенням на карти. Укладають відходи з автотранспорту у карти, далі розрівнюють шар бульдозери з ущільненням котками. Кожні 2-3 м ущільнених відходів засипають мінеральним грунтом шаром $0,25-0,3$ м.

Значна потужність насипних грунтів, представлених побутовим сміттям, що складається з органічних і неорганічних відходів, їх тривалий період консолідації та суттєва неоднорідність деформаційних властивостей є одним із несприятливих чинників. В процесі складування побутових відходів під впливом Таблиця 1 хімічних реакцій та атмосферних чинників виникає фільтрат, який негативно впливає на навколишнє природне середовище, і його без відповідного очищення не можна скидати в існуючі природні водойми.

Атмосферні опади, що випадають на звалище побутових відходів, та стікають з прилеглих до звалища схилів змішуються з фільтратом і теж стають непридатними для скидання в існуючі водойми. Це пов'язано 3 невиконанням заходів інженерного захисту територій і споруд полігонів ТПВ від небезпечних інженерно-геологічних явища бо взагалі їх відсутністю.

\section{Виклад основного матеріалу}

Території полігонів твердих побутових відходів в Україні характеризується складними геологічними та тектонічними умовами із стійкою тенденцією до розвитку понад десяти інженерно-геологічних процесів і явищ. Це - зсуви, затоплення, підтоплення, забруднення продуктами фільтрату грунтових вод тощо .

3 нормативної та наукової літератури [1-4] проаналізовано заходи інженерного захисту територій, які можна реалізувати при рекультивації полігонів твердих побутових відходів:

\begin{tabular}{|l|c|c|c|c|}
\hline \multirow{2}{*}{ Компоненти } & \multirow{2}{*}{$\begin{array}{c}\text { Загальні } \\
\%\end{array}$} & \multicolumn{3}{|c|}{ Склад, \% } \\
\cline { 3 - 5 } & & +200 & $-200-80$ & -80 \\
\cline { 3 - 5 } & 22,0 & 6,6 & 11,4 & 4,0 \\
\hline Папір, картон & 35,0 & 0,0 & 9,2 & 25,8 \\
\hline Продуктові і рослинні відходи & 5,5 & 3,3 & 2,0 & 0,2 \\
\hline Текстиль & 2,0 & 0,15 & 1,6 & 0,25 \\
\hline Пластмаса & 4,0 & 1,45 & 2.5 & 0,05 \\
\hline Полімерна плівка & 1,5 & 0,05 & 1,45 & 0,0 \\
\hline Шкіра, резина & 1,0 & 0,0 & 0.3 & 0,7 \\
\hline Кістки & 18,0 & 1,0 & 5,0 & 8,3 \\
\hline Інші включення & 4,0 & 1,3 & 2.5 & 0,2 \\
\hline Чорні метали (консервні банки) & 7,0 & 0,0 & 6,8 & 0,2 \\
\hline Скло (пляшки та інша тара) & & &
\end{tabular}


- зміна рельєфів схилів;

- регулювання стоку поверхневих вод;

- захист поверхонь схилів від інфільтрації зливових і талих вод у грунт та ерозійних процесів,

- дренажі для відводу фільтрату;

- підпірні стінки;

- стримувальні протизсувні споруди;

- агролісомеліорація.

1) Зміна рельєфів схилів. Згідно п.3.123 ДБН В.2.4-2-2005 нормативний кут схилу встановлюється залежно від цільового використання, наприклад:

- для оброблювання сільськогосподарських культур - не більше $2 \ldots 3^{\circ}$;

- для луків і пасовищ - не більше $5 . . .7^{\circ}$;

- для садів - не більше $11^{\circ}$;

- для посадки лісу (чагарників і дерев) - не більше $18^{\circ}$.

Для створення ухилу до $18^{\circ}$ (ДБН В.2.4-2-2005 зі зміною №1) передбачається на полігонах влаштувати плато, виположувати існуючі відкоси зі створенням нормативних ухилів 1:3,2 на конкретних ділянках.

Площа верхнього майданчика (так званого плато) профілюється для створення ухилів та відведення дощових і талих вод (ухил до 0,02).

2) Регулювання стоку поверхневих вод. Забруднена вода - це поверхневий стік з водозбірної площі та снігово-дощові опади, що потрапляють безпосередньо на ділянку, які просочилися крізь товщу ТПВ і очевидно в якійсь мірі розбавлені фільтратом.

Заходи регулювання рівня поверхневих вод передбачають по периметру карти полігону ТПВ влаштування водовідвідної канави з збірними колодязями, де збираються дощові води разом з фільтратом, з якої відводяться по мережі колекторів до каналізаційної насосної станції, а потім до очисних споруд.

Пропоноване конструкція організованого водовідведення (рис. 1) по рекультивації полігону передбачає влаштування організованого відведення дощових вод по периметру карти системою 3/б водовідвідних лотків. Дана система збору поверхневих та талих вод запроектована 3 лотоків, наприклад перерізом 360x570 (h) та 780x530 (h) з розрахунков- им наповненням 0,75 .

Далі дощові води відводяться відвідними колекторам діаметром $\varnothing 500$ мм та системи водобійних колодязів до існуючого водовідвідного каналу.

3) Захист поверхонь схилів від інфільтрації зливових і талих вод у грунт та ерозійних процесів. Багатофункціональний захисний екран поверхні полігону ТПВ призначений для збирання і відведення поверхневої (чистої) води і зменшення кількості фільтрату, збирання і утилізації біогазу.

Захисний екран влаштовується зверху технологічного екрану товщиною 1 м і складається з наступних конструктивних шарів (рис. 1):

- георешітка на укосах;

- шар родючого грунту завтовшки 30 см;

- суглинок 20 см;

- дренажний шар завтовшки не менше 20 см;

- шар синтетичної гідроізоляції геомембрани HDPE завтовшки 1,5 мм;

- геотекстиль 3,5 мм;

- газовий дренаж 30 см (щебінь фракції 30-40 мм)

- технологічний екран (суглинок) 25 см.

Геомембрана - це ізолююче покриття, що виготовлено із поліетилену високої щільності HDPE товщиною 1,5 мм з гладкою або структурованою поверхнею.

Геомембрана HDPE забезпечує повну ізоляцію навіть від токсичних речовин. Використання геомембрани HDPE як протифільтраційного екрану на полігоні твердих побутових відходів захищає грунтові води від забруднення, не реагує з хімікатами та токсичними речовими, стійка до ультрафіолетового випромінювання.

Монтаж рулонів геомембрани здійснюють механізовано. Монтажним краном траверсу з килимом укладають на шар геотекстиля. Геомембрана вкладається вільно без натягу з перекриттям попередньої полоси на 10-15 см (рис. 2).

Для зварювання полотнищ геомембрани використовується високоякісне зварювальне обладнання компаніï Leister (Швейцарія) і компанії Herz (Німеччина) подвійним швом або екструзійним методом. Під час зварювання подвійним швом утворює-

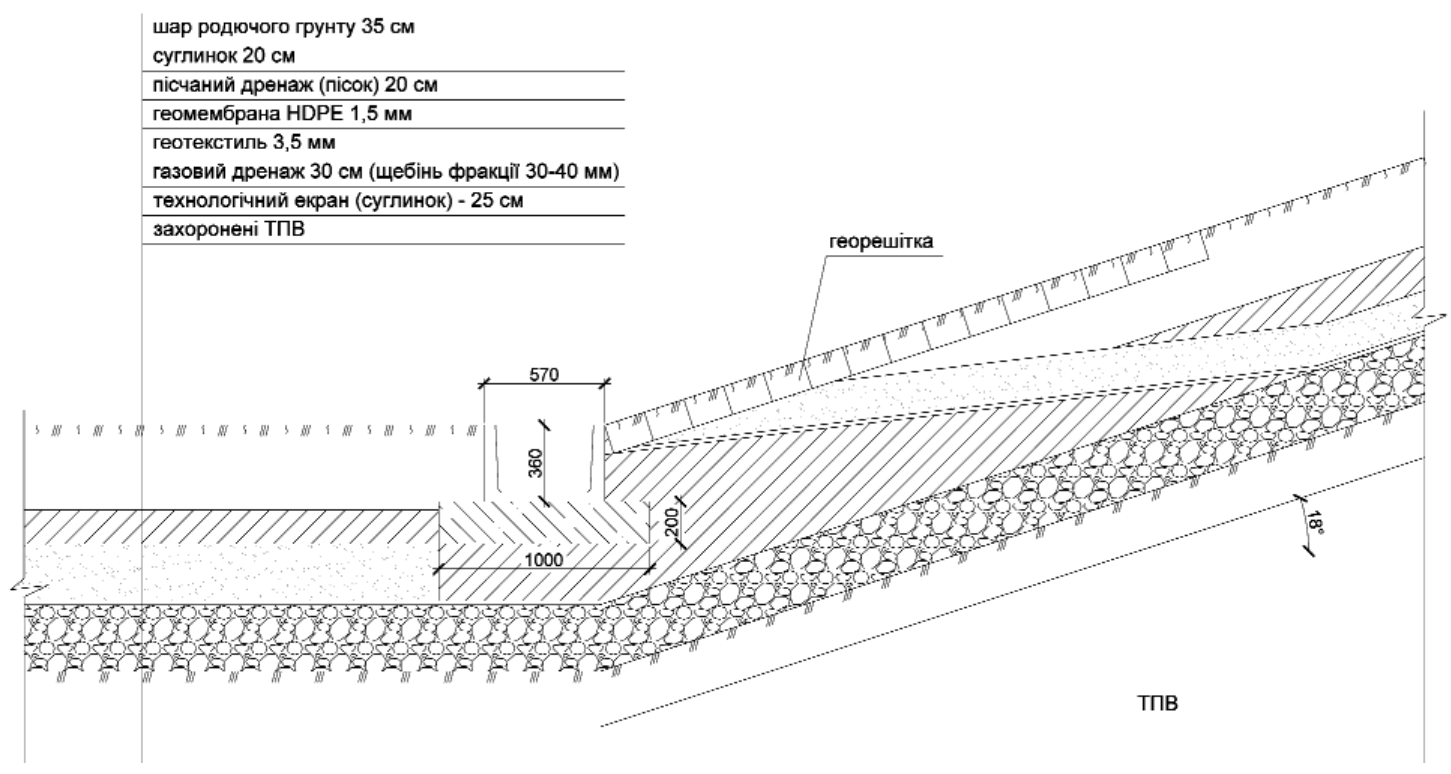

Рис. 1. Конструкція організованого водовідведення з карти полігону 


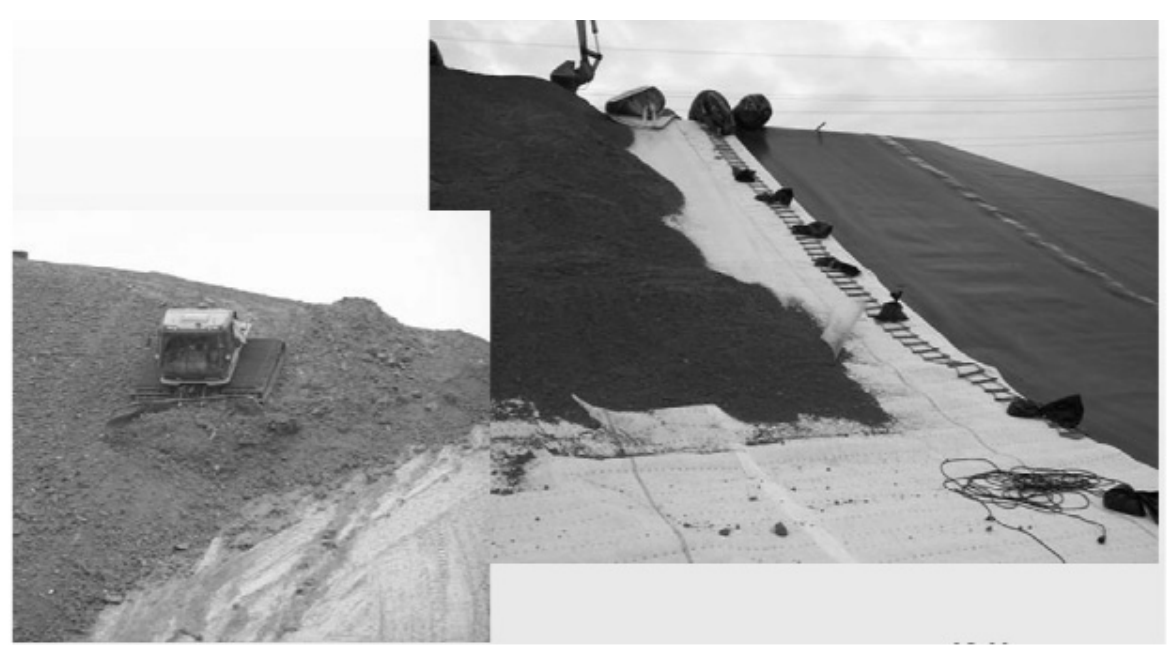

Рис. 2. Схеми влаштування геомембрани HDPE

ться повітряний канал, який дозволяє контролювати якість і герметичність шва. Екструзійний метод застосовується, коли немає можливості використовувати устаткування для виготовлення подвійного шва. Наприклад, Т-подібні шви, складні конструктивні вузли, місця проходу інженерних комунікацій, а також в разі механічного пошкодження геомембрани. Для цього використовується зварювальний пруток, виготовлений $з$ того ж сировини, що і геомембрана.

На відкосах геомембрану монтують автомобільним краном, який знаходиться у найвищій точці схилу.

Проїзд механізмів і автотранспорту по вкладеній геомембрані заборонено. Для виключення впливу вітру і утворення парусності необхідне тимчасове привантаження полотнищ мішками 3 грунтом. При влаштуванні захисного шару рух бульдозера при відсипанні і розрівнюванні шарів повинен проводитися вздовж з'єднувальних волокон.

4) Дренажі для відводу фільтрату

Для недопущення розтікання фільтрату за межі звалища вздовж його відкосів передбачено трубчастий дренаж з оглядовими колодязями для збору та відведення фільтрату.

Переважна більшість полігонів ТПВ по периметру обладнані трубчастою дренажною системою для збору фільтрату, наприклад з труб діаметром 300 мм і оглядові колодязі діаметром 1 м. 3 дренажної системи фільтрат відводиться до насосної станції, а далі - у відстійники.

Досвід багаторічних обстежень науковими співробітниками ДП "Науково-дослідний інститут будівельного виробництва" гідротехнічних споруд, в тому числі гідротехнічних споруд полігону ТПВ №5 в Підгірці Обухівського району Київської області, свідчить, що за період експлуатації оглядові колодязі дренажної системи, лотки та трубопроводи засмічені продуктами звалища або повністю затоплені.

В зв'язку з існуючою ситуацією пропонується влаштувати нову дренажну систему збору та відведення фільтрату з полігону до каналізаційної насосної станції, потім до локальних очисних споруд, а також демонтаж існуючих залізобетонних конструкцій оглядових колодязів та використання їх при влаштуванні нової дренажної системи.

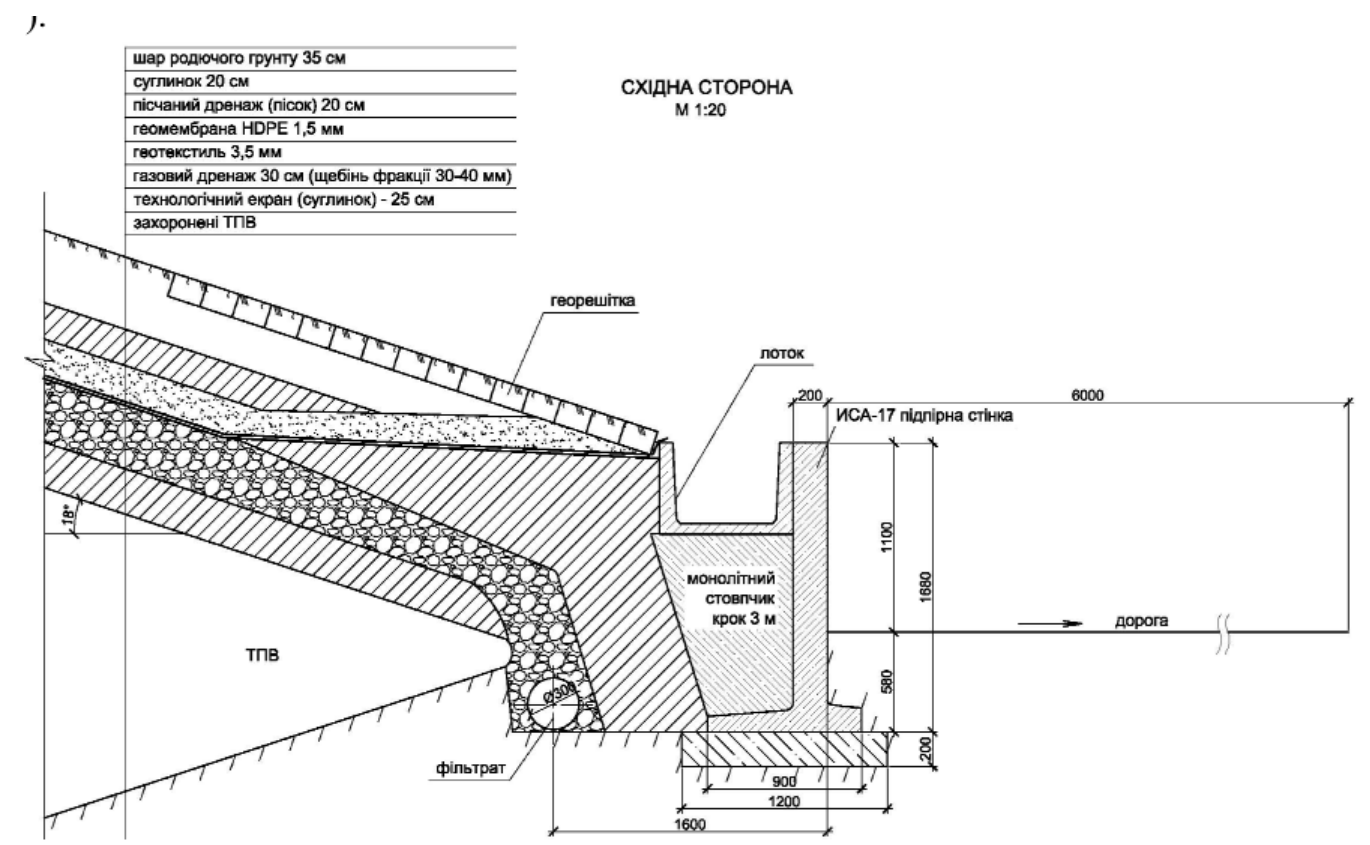

Рис. 3. Конструкція підпірної стінки 


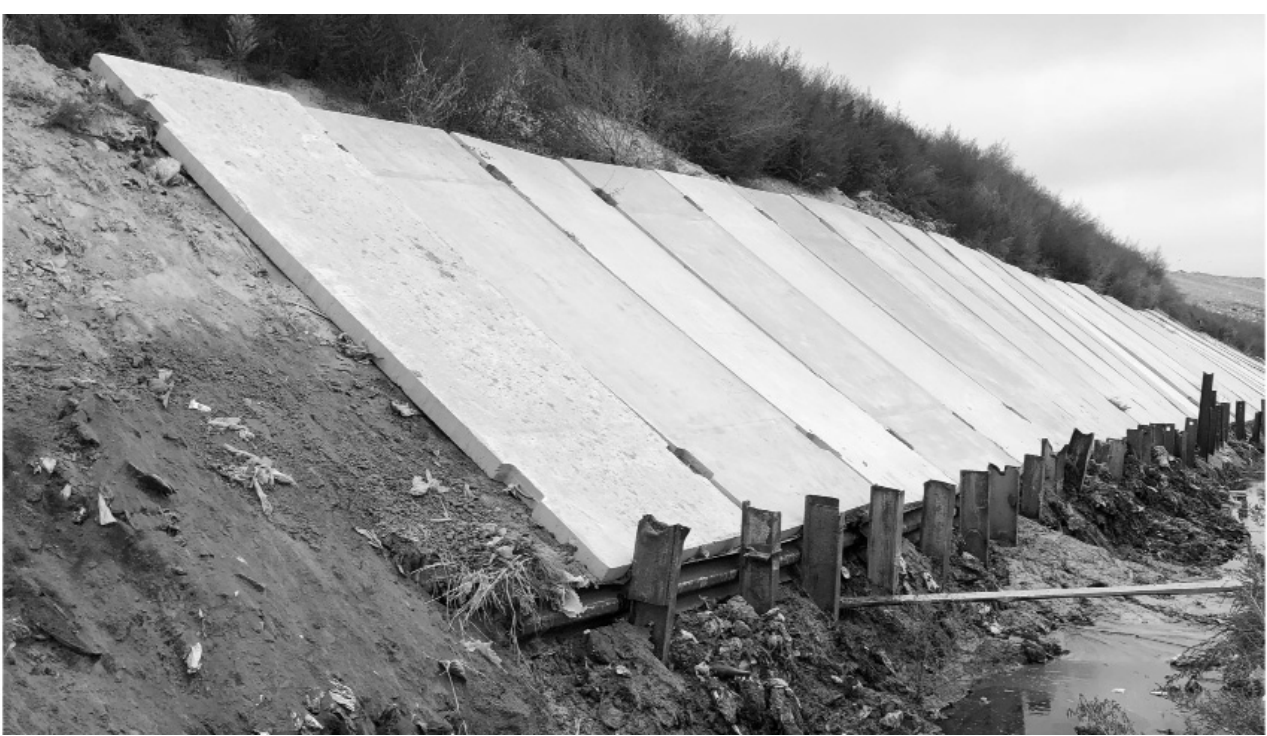

Рис. 4. Приклад влаштування стримувальної протизсувної споруди на полігоні ТПВ №5 в Підгірці Обухівського району Київської області 2018 рік

Для відведення забрудненої води (фільтрату) з карти рекомендується влаштування тришарового дренажу із щебеню типу "зворотний фільтр". Дренажний матеріал - щебінь, укладається шарами у трапецеподібну траншею. В центр призми укладається дренажна перфорована поліетиленова труба 315 мм, яка огорнута геотекстилем. Верхня частина труби перекривається трьома шарами щебеню різної фракції. Таким чином формуються декілька дрен, які відводять воду до водоприймального колодязя дренажної насосної станції перекачки стоку.

5) Підпірна стінка. Підпірна стінка є частиною огородження твердих побутових відходів. Її необхідність викликана стислими умовами - неможливістю зміни рельєфу схилів до проектних ухилів та забезпечення стійкості укосів в межах відведеної території полігону. В даному випадку пропонується збірна з/б підпірна стінка з серійної кутової панелі ИСА-17 висотою $\mathrm{H}=1,68$ м. Обпирання ㄲï відбувається на монолітну плиту товщиною 200 мм опорною частиною шириною 900 мм.

Підпірна стінка складає єдину конструкцію разом з дощовідвідними лотками (рис. 3).

6) Стримувальні протизсувні споруди. Для попередження зсувів та обвалів, зниження тиску від грунтових мас, які можуть зміститися, і стабілізації положення схилів було запропоновано декілька варіантів стримувальних протизсувних споруд.

У першому варіанті пропонувалось в зоні лотка встановити на палях кутові (чобіткові) панелі, а простір між вертикальною стінкою і аварійним схилом додатково засипати грунтом.

За другим варіантом було запропоновано укрити нижню частину схилу залізобетонними плитами довжиною 6 м і піджимати їх до ТПВ металевими фермами, встановленими на палях.

У третьому варіанті залізобетонні плити розміром 6х2 м вагою 4,8 т укладають поперек схилу i з'єднують між собою у верхній частині через накладки, а у нижній частині до закладних металевих паль. Для цього використовуються металеві палі із двотавра №24 довжиною близько 6 м, крок паль складає 1 м. Товщина плити дорівнює 0,22 м. В підсумку, аварійна ділянка схилу буде нібито замкнута в залізобетонний корсет. Площа обпирання плити на грунт повинна складати не менше $80 \%$.

Кожний із запропонованих варіантів при відповідному техніко-економічному обгрунтуванні може бути використаний. Третій варіант влаштування стримувальної протизсувної споруди був реалізований для підсилення аварійної ділянки схилу полігону ТПВ №5 в Підгірці Обухівського району Київської області у 2018 році (рис. 4).

7) Агролісомеліорація передбачає посів багаторічних трав, створення ріллі для технічних культур, газонів, садіння чагарників, саджанців декоративних дерев, дерев для утворення парків та садів. Агролісомеліорація проводиться після на завершальному етапі закриття існуючої карти полігону ТПВ, тобто процесу зміцнення звалищного грунту, досягнення ним постійного стійкого стану.

\section{Висновок}

У процесі тривалої експлуатації карти полігонів твердих побутових відходів і сусідні території засмічені продуктами звалища, фільтрат, який просочується з побутового сміття, разом з атмосферними опадами негативно впливає на навколишнє природне середовище. Як підказує досвід обстежень гідротехнічні споруди полігонів також засмічені продуктами звалища або повністю затоплені. Це пов'язано з невиконанням заходів інженерного захисту територій і споруд полігонів ТПВ від небезпечних інженерногеологічних явищ і їх відсутністю.

У даній роботі проаналізовано заходи інженерного захисту територій, які можна реалізувати при рекультивації полігонів твердих побутових відходів. Це - зміна рельєфів схилів, регулювання стоку поверхневих вод; захист поверхонь схилів від інфільтрації зливових і талих вод у грунт та ерозійних процесів, дренажі для відводу фільтрату, підпірна стінка, стримувальні протизсувні споруди, агролісомеліорація. Запропоновані конструктивні рішення рекультивації полігонів ТПВ кожного із заходів інженерного захисту при техніко-економічному обгрунтування дозволить вибрати в кожному окрему випадку найбільш ефективні. 


\title{
Jimepamypa
}

1. ДБН В.1.1-3-97. Інженерний захист територій, будинків і споруд від зсувів та обвалів. Основні положення.

2. ДБН В.1.1-25-97. Інженерний захист територій та споруд від підтоплення та затоплення. - К.: Мінрегіонбуд України, 2010. - 52 c.

3. Інженерна підготовка територій населених місиь: Навчальний посібник / За ред.. Линника I.Е. - Харків: ХДАМГ, 2004. $-337 \mathrm{c}$.

4. Великодний Ю. Й. Захист територій від зсувів: Навчальний посібник/ Ю. Й Великодний - Полтава: ТОВ "Поліграфиентр Скайтек", 2006.-116 с.

5. Інженерний захист та освоєння територій: Довідник \За ред.. В. С. Нішук, - К.: "Основа", $2000 .-334$ c.

6. ДБН В.2.4-2:2005 "Полігони твердих побутових відходів. Основні положення проектування зі Зміною №1 ";

7. ДСТУ 3910-95 "Класифікація відходів" "Санитарные правила устройств и содержания полигонов твердых бытовых отходов". №2811-83.

\section{References}

1. DBN V.1.1-3-97. Inzhenerny j zaxy st tery torij, budy `nkiv $i$ sporud vid zsuviv ta obvaliv. Osnovni polozhennya.

2. DBN V.1.1-25-97. Inzhenerny `j zaxy st tery torij ta sporud vid pidtoplennya ta zatoplennya. - K.: Minregionbud Ukrayiny`, 2010. $-52 s$.

3. Inzhenerna pidgotovka tery`torij naseleny`x miscz`: Navchal`ny`j posibny`k / Za red.. Ly`nny`ka I.E. - Xarkiv: XDAMG, 2004. $-337 s$.

4. Vely`kodny`j Yu.J. Zaxy`st tery torij vid zsuviv: Navchal `ny j posibny`k/ Yu.J Vely`kodny j - Poltava: TOV «Poligrafcentr Skajtek», 2006.-116s.

5. Inzhenerny j zaxy `st ta osvoyennya tery torij: Dovidny`k \Za red.. V. S. Nishhuk, - K.: «Osnova», 2000.- 334 s.

6. DBN V.2.4-2:2005 "Poligony tverdy`x pobutovy ‘x vidxodiv. Osnovni polozhennya proektuvannya zi Zminoyu \#1 ";

7. DSTU 3910-95 «Klasy fikaciya vidxodiv» «Sany tarnue pravy la ustrojstv y` soderzhany ya poly gonov tverdbux butovbux otxodov». \#2811-83.

А.В. Мурасьова, заместитель заведующего отделом

ГП "Научно-исследовательский институт строительного производства", г.. Киев

И.М. Уманец, к.т.н., доц. каф. ТБО

Киевский национальный университет строительства и архитектуры., Г. Киев

\section{СРЕДСТВА ИНЖЕНЕРНОЙ ЗАЩИТЫ ТЕРРИТОРИЙ ПОЛИГОНА ТВЕРДЫХ БЫТОВЫХ ОТХОДОВ}

\begin{abstract}
Аннотация. В статье проанализированы меры инженерной защиты территорий, которые могут быть внедрены при рекультивации полигонов твердых бытовых отходов. Это - изменение рельефов склонов с нормативными уклонов 1: 3,2, регулирование стока поверхностных вод; защита поверхностей склонов от инфильтращии ливневых и тальх вод в почву и эрозионных процессов, то есть устройства многофункционального зашитного слоя (суглинок 25 см; газовый дренаж 30 см; геотекстиль 3,5 мм; геомембраны НDPE 1,5 мм; песок 20 см; суглинок 20 см; плодородная почва 30 см; георешетка на откосах), дренажи для отвода фильтрата, подпорная стенка, сдерживающие противооползневые сооружения, агролесомелиорации. Предложены конструктивные решения мер инженерной зашиты территорий полигонов твердых бытовых отходов в нескольких вариантах и технологии их устройства.

Ключевые слова: изменение рельефов склонов; защитный экран; дренаж; подпорная стенка; сдерживающие противооползневые сооружения; агролесомелиорации.
\end{abstract}

O.V. Murasova, deputy head of the department

State Enterprise "Research Institute of Construction Production", Kyiv

I.M. Umanec, Ph.D., Assoc. cafe TBV

Kyiv National University of Construction and Architecture, Kyiv

\section{MEANS OF ENGINEERING PROTECTION OF TERRITORIES OF POLYGONS OF SOLID HOUSEHOLD WASTE}

\begin{abstract}
The article analyzes the measures of engineering protection of territories that can be implemented during the reclamation of landfills of solid household waste. This is a change in the reliefs of the slopes to the standard deviations 1: 3,2, the regulation of the runoff of surface water; protection of slopes surfaces from infiltration of storm and thawed water in the soil and erosion processes, ie arrangement of a multifunctional protective layer ( $25 \mathrm{~cm}$ loam, $30 \mathrm{~cm}$ gas drainage, $3.5 \mathrm{~mm}$ geotextile, $1.5 \mathrm{~mm}$ HDPE geomembrane, $20 \mathrm{~cm}$ sandstone, $20 \mathrm{~cm}$ loam ; fertile soil $30 \mathrm{~cm}$, geogrids on slopes), drainages for drainage of filtrate, retaining wall, restraining anti-landslide structures, agroforestry. The constructive decisions of measures of engineering protection of territories of solid waste landfills in several variants and technologies of their installation are offered. Keywords: change of reliefs of slopes; protective screen; drainage; retaining wall; containment landslide structures; agroforestry.
\end{abstract}

